\title{
Possible Relationships between Seep Carbonates and Gas Hydrates in the Miocene of the Northern Apennines
}

\author{
Stefano Conti and Daniela Fontana \\ Department of Earth Sciences, University of Modena and Reggio Emilia, Via S. Eufemia 19, 41100 Modena, Italy \\ Correspondence should be addressed to Daniela Fontana, daniela.fontana@unimore.it
}

Received 12 April 2011; Accepted 13 June 2011

Academic Editor: Umberta Tinivella

Copyright (C) 2011 S. Conti and D. Fontana. This is an open access article distributed under the Creative Commons Attribution License, which permits unrestricted use, distribution, and reproduction in any medium, provided the original work is properly cited.

In the Miocene of the northern Apennines, a widespread carbonate precipitation was induced by the expulsion of methane-rich fluids. Numerous outcrops of carbonate masses share sedimentological, textural and geochemical features with present-day gas hydrate-associated carbonates. We hypothesize the contribution of paleo-gas hydrate destabilization on the base of the heavy oxygen isotope signature, the presence of distinctive sedimentary features (breccias, pervasive nonsystematic fractures, and soft sediment deformation), the close association between seep carbonates and sedimentary instability, and the huge dimensions of seep carbonates bearing brecciated structures.

\section{Introduction}

Authigenic 13C depleted carbonates have actually been described to form within or in proximity to gas hydrates, and gas hydrate-associated carbonates have been sampled from present-day settings in direct contact with the sea-floor or a few meters below it [1-3]. These seep carbonates, called clathrites [4, 5], show peculiar lithologies and structures such as vacuolar or vuggy-like structures resembling the shape of gas hydrate bubbles, monogenic and polygenic breccias, resulting from the rapid destabilization of gas hydrates. Highly brecciated structures are usually reported and restricted to large chemoherm complexes $[1,6,7]$.

It is well known [8] that gas hydrate stability depends on temperature, pressure, and availability of gas and water. Different geologic processes, such as sea-level drop, tectonic uplift, climate changes, and hot fluid rise, can induce the destabilization of gas hydrates. Their destabilization causes the release of huge amounts of fluids (gas and water), thus triggering large-scale continental slope instability: slumps, slides, mud diapirism and seafloor collapses. Gas hydrate destabilization can also affect the oxygen isotope composition due to the release of 18O-enriched water (see [9] and references therein).
Very few examples of seep carbonate-rich rocks recording the formation of gas hydrates within the sedimentary column have been documented [10-14]. Gas hydrates cannot survive for long geological times either because buried sediments are submitted to increasing geothermal conditions or are tectonically uplifted. In fossil sediments, the study of the interaction between seep carbonates, hydrate destabilization, and sediment instability is particularly difficult, owing to the lack of a direct recognition of fluid seepages and to the absence of precise quantifications of paleoenvironmental factors (pressure, temperature, and paleodepth) conditioning hydrate stability conditions.

Following present-day analogues, the only means to infer a possible role of gas hydrates in fossil seep carbonates are geochemical (oxygen isotope signature) and textural (presence of distinctive sedimentary features such as breccias, pervasive nonsystematic fractures, and soft sediment deformation) described in clathrites. Additional evidences can derive from the close association between seep carbonates and sedimentary instability, and the large dimensions of seep carbonate masses bearing brecciated structures.

Cold seep carbonates and associated lithologies were discovered in various geological settings of the northern Apennines during the Miocene [15-18] (Figure 1). Many 

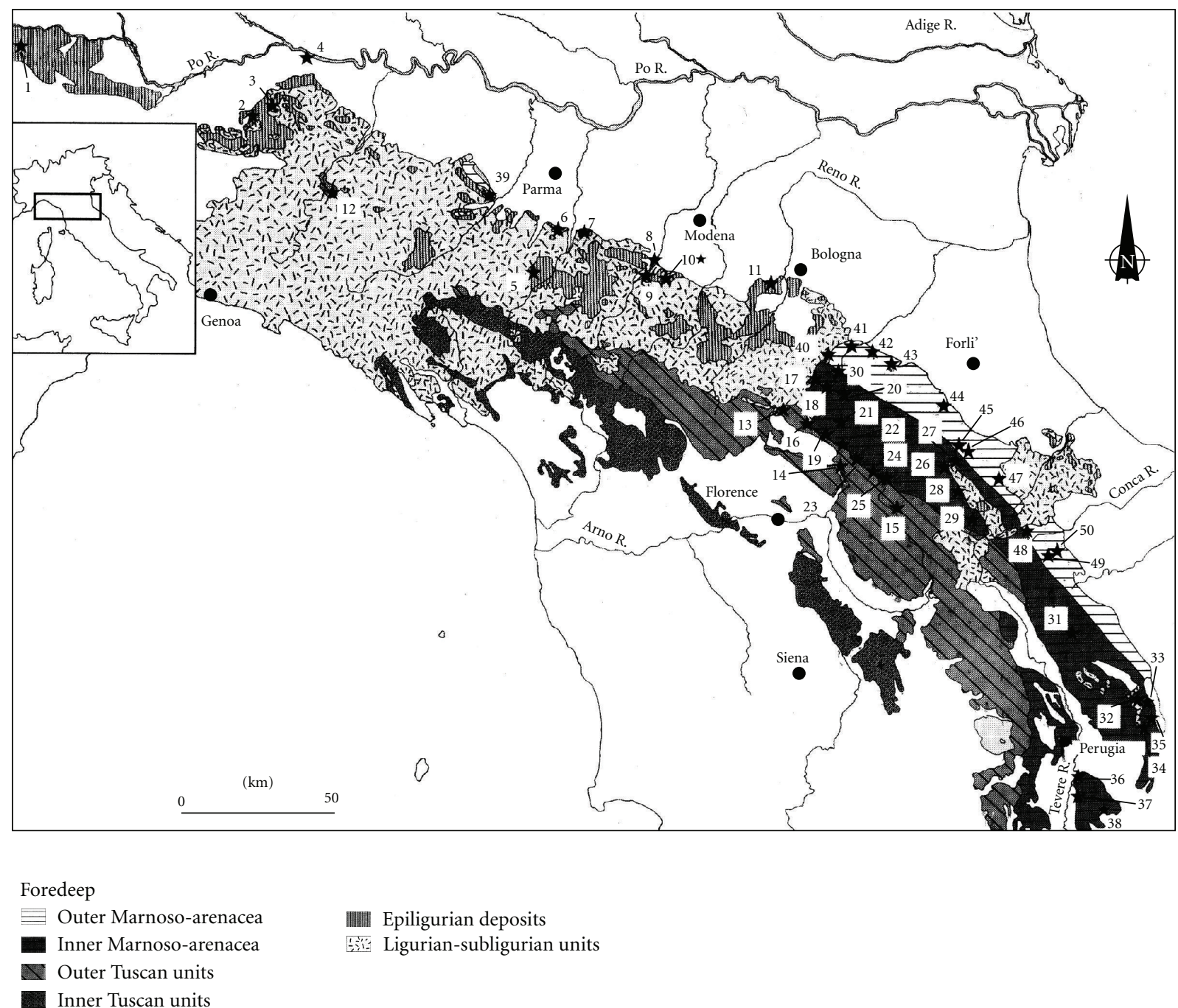

Epiligurian deposits

T:i: Ligurian-subligurian units

FIGURE 1: Seep carbonates of the northern Apennines (stars). Numbers 1-11 refer to outcrops enclosed in the Epiligurian deposits, 12-15 in the Tuscan Units, and 16-50 in the Marnoso-arenacea and related slope mudstones. The outcrops considered in this work are 10 referring to Sasso Streghe, Le Prade, Montandone; 25 to Castagno d'Andrea; 47 to Montepetra and 48 to Poggio delle Campane (modified from [15]).

seep carbonates are characterized by negative $\partial^{13} \mathrm{C}$ and positive $\partial^{18} \mathrm{O}$ values, by various types of brecciated structures and fluid-flow conduits, and are associated with intense sediment instability such as slumps, intraformational breccias, and olistostromes. In this paper, we report the results of 12 years of studies on seep carbonates, obtained from field work, facies analysis, geochemistry, and biostratigraphy, focussing on structures and clues highlighting the seepage activity and the possible relationships with gas hydrate destabilization.

\section{Geological Setting}

The northern Apennines is a thrust and fold belt characterized by the stacking of several structural units of oceanic and continental origin (Figures 1 and 2). The complex structure of the chain is the result of the convergence and collision between the European and the Adria plates from the Mesozoic to the present. Starting from the Early Cretaceous, an intraoceanic accretionary prism caused the progressive consumption of the Piedmont-Ligurian Ocean, a portion of the Tethys ([20] and references therein). The complete closure of the ocean during Middle-Late Eocene caused the rapid uplift and erosion of the Alpine orogenic wedge and the inception of the continental collision. During the collision (late Oligocene to Recent) the internal oceanic units (Ligurian units), which were deformed and accreted during the Alpine orogenesis, were placed over the western continental margin of Adria while the thrust system migrated toward the foreland involving the Tuscan and Umbrian units, which were deposited on the Adria plate (Figure 2) [21-23]. Foredeep basins have developed and migrated easterly and northeasterly in response to the advancing Apenninic fronts which progressively have accreted the foredeep deposits (Figure 2). Starting from late Oligocene, the migration of the thrust belt was coupled with the counterclockwise rotation of the Corsica-Sardinia block and of the northern Italian peninsula $[24,25]$. 


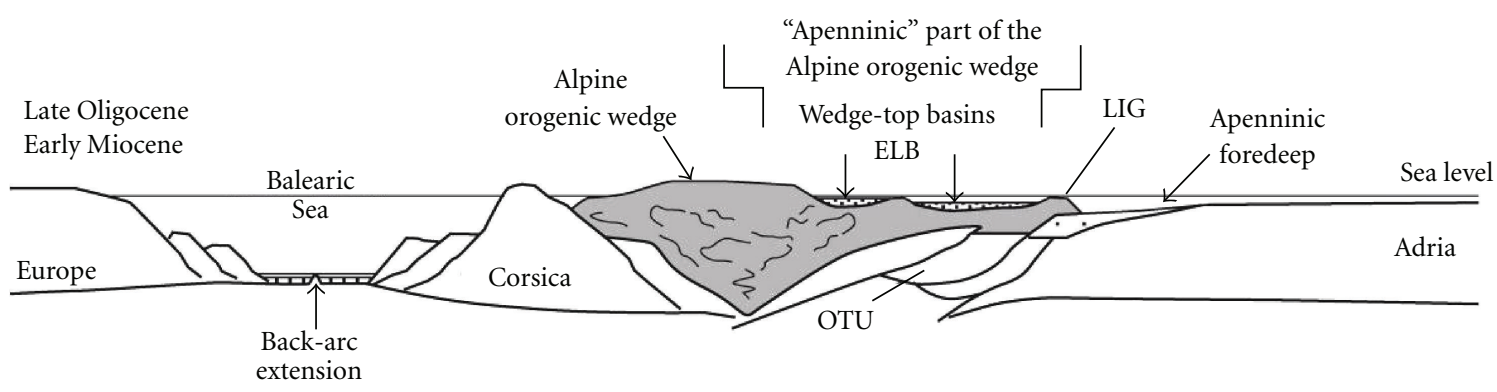

(a)



(b)

FIGURE 2: Schematic sketch of the migration of the Apennine thrust-belt foredeep system. (a) From the Late Oligocene to Early Miocene. (b) In the Late Miocene, ELB: Epiligurian basin, OUT: outer Tuscan Units, LIG: Ligurian Units (modified from [19]).

At present, the Apenninic orogenic wedge is framed by two superposed structural levels. The upper, allochthonous structural level is made up of the accreted Ligurian units. These comprise Mesozoic oceanic and forearc deposits derived from the closure of the Ligurian-Piedmont ocean and its continental margins [26]. On top of the Ligurian units, the Epiligurian wedge-top basins are characterized by a middle Eocene-early Messinian succession [27-29]. The lower structural level (Tuscan-Umbrian Units) consists of metamorphic basement and Mesozoic to Paleogene carbonate successions folded and segmented by thrusts.

The Miocene paleogeography of the northern Apennine orogenic wedge and associated foredeep basin is depicted in Figure 2. The foredeep depocenters and Epiligurian wedgetop basin migrated in response to the advancing orogenic leading edges. At the same time, the external ramp was migrating and flexing toward outer areas of the foreland basin. The foredeep depocenters were mainly filled by sheetlike turbiditic deposits derived from fluvial and deltaic systems draining the Alps. By contrast, the Epiligurian clastic deposits testify to local Apenninic sources [30]. Deltaic turbiditic systems are mainly located on the orogenic wedge and wedge-top basins; mixed turbiditic systems are at the leading edges of the orogenic wedge and inner foredeep; deep marine turbiditic systems are situated in axial foredeep depocenters and on the foreland external ramp.

In the northern Apennines, mass-wasting products (slumps, slides, block falls, and debris and flows), also known as olistostromes, are common [31,32]. They occur either in the Epiligurian wedge-top basin, or close to the toe of the orogenic wedge $[33,34]$, and even in the inner part of the foredeep basins [35]. They might be related to instability



Figure 3: Castagno d'Andrea carbonates (number 25 of Figure 1), the basal part of the body is severely brecciated.

caused by fluid seepage [36]. They form complex units of various sizes, from a few meters to hundreds of meters, and derive from masses of both foredeep deposits and Ligurian units slided off submarine slopes.

\section{Apennine Seep Carbonate Distribution and Characters}

Authigenic seep carbonates in the northern Apennines are concentrated in Middle-Late Miocene pelitic successions in two different geological settings: in the foredeep and in Epiligurian wedge-top basins (Figures 1 and 2) [15, 37]. In the foredeep, seep carbonates (Figure 3) occur in marly and clayey hemipelagites and fine-grained turbidites, located in the inner slope (closure facies), and in intrabasinal highs in the inner side of the foredeep 


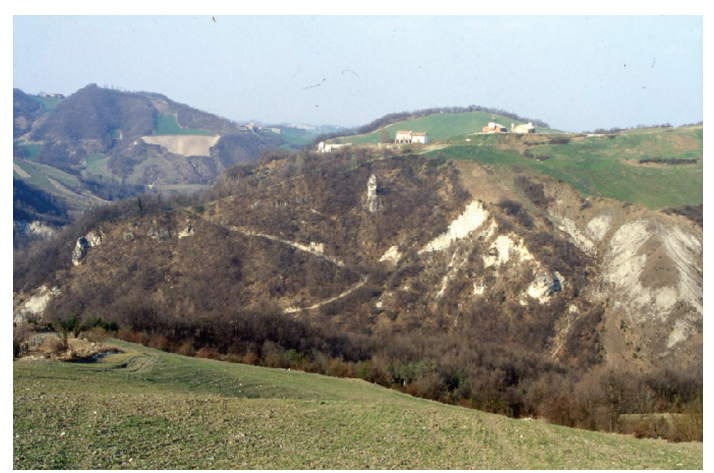

FIgURE 4: Sasso Streghe carbonates (number 10 of Figure 1): note the large pinnacle in the middle, and the lateral extension of the body on the left. On the right the diapiric mélange of Montardone crops out (argillaceous badlands).

(pelitic intervals of [38]). Closure facies are essentially slope deposits, Langhian-early Messinian in age, thinning laterally and capping huge arenaceous turbiditic bodies (Monte Cervarola and Marnoso-arenacea Fms). Pelitic intervals are Langhian-early Serravallian in age, intercalated within Monte Cervarola and Marnoso-arenacea Fms; they are composite bodies, including intraformational and subordinate extraformational sediments, with a lateral extent of 10 $30 \mathrm{~km}$. The intraformational sediments are basin plain and slope lithofacies, partly involved in spectacular megaslumps. The extraformational are Ligurian, Subligurian, Epiligurian, or Tuscan deposits, derived from the migrating thrust front.

In the Epiligurian basins, seep carbonates occur in the lower part (Serravallian-early Tortonian) of the pelitic Termina Marls Formation (Figure 4).

In the field, seep carbonates occur in a variety of morphologies: lenticular-amygdaloid or scattered irregular bodies, pinnacles, irregularly thickened levels ranging in diameter from a few centimeters to several decameters (Figures 3 and 4). The maximum thickness is about $30 \mathrm{~m}$. They are commonly poorly stratified and strongly bioturbated (as indicated by burrows, mottled structures, and trace fossils), but some seep carbonates show a clear stratification. The marly and fine calcarenitic lithofacies are typically associated with abundant fossil remains, consisting of thick recrystallized closed shells and moulds of lucinid and vesicomyid-like clams, thin shells of modioloid-like mussels, and small gastropod shells. The fossil preservation shows unabraded condition; lucinid-like shells can be very large (up to $25 \mathrm{~cm}$ ), thick and articulated, and so densely packed as to represent a striking feature of the deposit. In contrast, coarser facies are markedly impoverished in fossil content; bivalve coquina is abundant and valves, when articulated, are generally isolated or more often packed but disarticulated.

Seep carbonate dominant rock types are calcilutitic/marly limestones, calcareous marls, and calcarenites. Enclosing sediments are hemipelagic/turbiditic mudstones, muddy sandstones, and marlstones, characterized by low permeability but severely fractured.

\section{Evidence of Paleo-Gas Hydrates in Seep Carbonate Formation}

Following present-day analogues (described in great detail by [1]), the only means to infer a possible role of gas hydrates in fossil seep carbonates are (1) the heavy oxygen isotope signature, (2) the presence of distinctive sedimentary features (breccias, nonsystematic fractures, and soft sediment deformation) linked to clathrites, (3) the close association between seep carbonates and sedimentary instability, and (4) the huge dimensions of seep carbonate deposition bearing brecciated structures.

Among seep carbonates of the northern Apennines, numerous outcrops show the peculiar features listed above, that could suggest relationships with gas hydrate destabilization.

In this paper we have selected four significant outcrops covering a wide area from Modena to Tuscan-Marchean Apennines (Figure 1). Three are in the foredeep: Montepetra (47 of Figure 1) and Poggio delle Campane (48) enclosed in the inner slope hemipelagites (closure facies), and Castagno d'Andrea (25) in the pelitic intervals of the foredeep. Sasso Streghe (10 of Figure 1, which includes several bodies) is located in the Epiligurian wedge-top basins.

These outcrops are made of large carbonate bodies characterized by negative $\partial^{13} \mathrm{C}$ and positive $\partial^{18} \mathrm{O}$ values, by various types of brecciated structures and fluid-flow conduits, and are associated with intense sediment instability such as slumps, intraformational breccias, and mud diapirs. In the following section we report data from field work, facies analysis, petrography, geochemistry, and biostratigraphy, focussing on features indicating possible relationships with gas hydrate destabilization.

\subsection{Clathrite-Like Structures}

4.1.1. Dimensions. In the field, the examined carbonates consist of huge isolated lenticular-amygdaloid, stratiform bodies and pinnacles ranging in extension from 10 to $100 \mathrm{~m}$ and with a maximum thickness up to $30 \mathrm{~m}$ (Figures 3 and 4). They can be laterally repeated with a close distribution and disposed in irregular thickened levels as long as 200$300 \mathrm{~m}$. The lateral distribution of levels is conformable with the stratification of the enclosing mudstones, and the lateral contact with host sediments varies from sharp to transitional.

4.1.2. Seepage-Induced Breccias. Monogenic, and polygenic breccias are abundant and generally restricted to the basal portion of carbonate bodies. Monogenic breccias (Figure 5) are made of heterometric angular clasts, ranging in size from few millimeters to 5-10 centimeters, composed of the authigenic micrite from the seep carbonates. Clasts are chaotically dispersed in a micritic matrix or in a fine to medium-grained sandy matrix. Larger clasts derive from the coalescence of heterometric smaller clasts, testifying various cycles of cementation and fragmentation. In many cases, monogenic breccias pass gradually to a dense network of nonsystematic carbonate-filled veins and microfractures, 


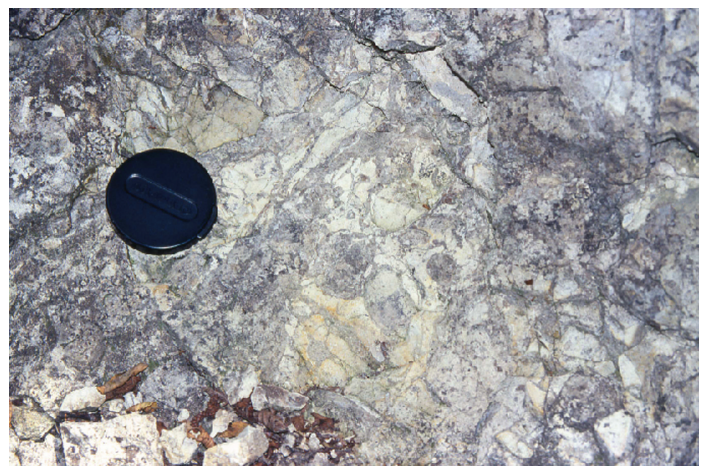

Figure 5: Monogenic breccias and irregular network of veins, Poggio delle Campane (number 48 of Figure 1).

irregularly connected to a larger vein network. Fossils are commonly reworked and disarticulated; they occur as isolated shells or are organized in discontinuous levels; layers of shell detritus are also present. Lateral extension is decimetric to metric.

Polygenic breccias (Figure 6) are characterized by a complex framework of carbonate, arenitic, and pelitic clasts of various provenance (both extraformational and intraformational) and dimensions, chaotically floating in the micritic matrix. Clasts are heterometric (from some millimeters to 50 centimeter in diameter), generally very angular, rarely subangular; sometimes clast size gradually decreases from the base to the top of carbonate masses. Intraformational clasts are made of carbonates from the various facies, or are supplied by lithotypes of the host turbidites and hemipelagites. Extraformational clasts derive from various sources such as Ligurian, sub-Ligurian, Epiligurian or foredeep arenaceous turbidites (Tuscan units) older than those including seep carbonates. Allochthonous clasts can also derive from the Ligurian nappe front and are now intercalated within foredeep or Epiligurian sequences. Fossils are scarce to absent and commonly disarticulated or represented by bivalve coquina in packstones or grainstones. In few cases, polygenic breccias are clast-supported. They form units ranging in thickness from some centimeters to a few meters, randomly distributed and often interdigitated with fine-grained carbonate cemented sediments. Pseudofluidal textures are observed.

4.1.3. Textures. Examined seep carbonates show many structures similar to those reported by [1] in the Hydrate Ridge gas hydrate-associated carbonates. Micritic-marly limestones and fine calcarenites show vacuolar and vuggy-like fabrics, and stromatactis-like structures resembling drusy crystals. Vuggy structures are often associated with irregular patches of monogenic carbonate breccias and irregular network of carbonate-filled veins (Figures 7, 8, and 9).

Void infillings are made up of carbonate cements and/or coarser sediments (calcarenites, microbreccias, and coquina debris). The abundance of veins and fractures of centimetric dimension give the carbonate masses the appearance of megabreccias. In thin section the micritic groundmass is crosscut by an intertwined network of irregular fissures.

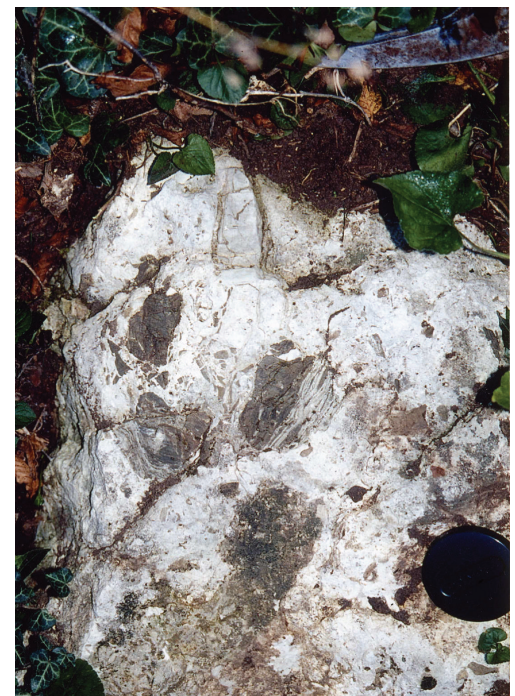

Figure 6: Polygenic breccias: clast dimensions vary from some mm to about $20 \mathrm{~cm}$. Sasso Streghe (number 10 of Figure 1).

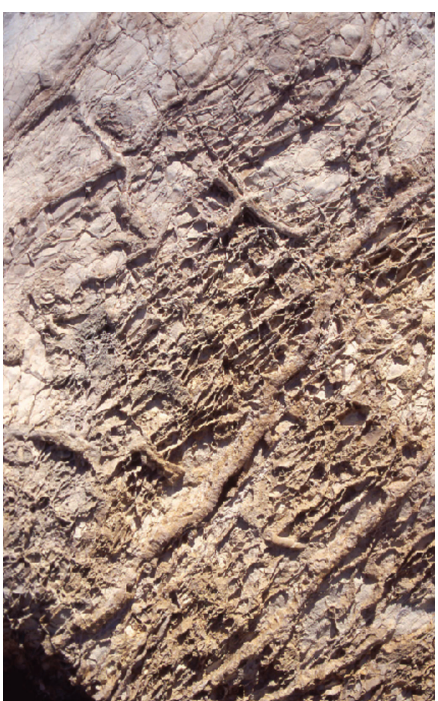

Figure 7: Micritic limestones with dense network of carbonatefilled veins and conduits. Maximum diameter of conduits is $2 \mathrm{~cm}$. Colline, near Castagno d'Andrea (number 25 of Figure 1).

Vein diameter ranges from 1-2 millimeters to 2 centimeters, they are not systematic and show a sinuous to irregular distribution; in most cases they can join forming veins of major dimensions $(1-2 \mathrm{~cm})$ containing abundant black iron sulfides. In some cases, veins and rims are lined by acicular or botryoidal aragonite. The vein infillings can also contain coquina debris.

4.1.4. Sediment Instability. The examined seep carbonates occur in deposits associated with intense sediment instability, such as intraformational slumps, soft-sediment deformation structures, and mud diapirs. Slumps and slides predominate in the foredeep (Montepetra, Poggio delle Campane, 


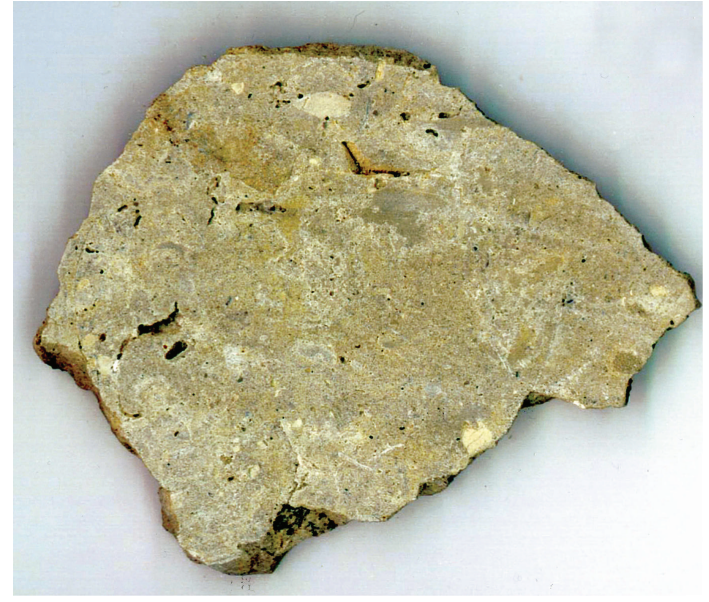

FIGURe 8: Micritic limestones with extensive vuggy and spongy fabric; maximum dimension of cavities is $1 \mathrm{~cm}$, Sasso Streghe (number 10 of Figure 1).

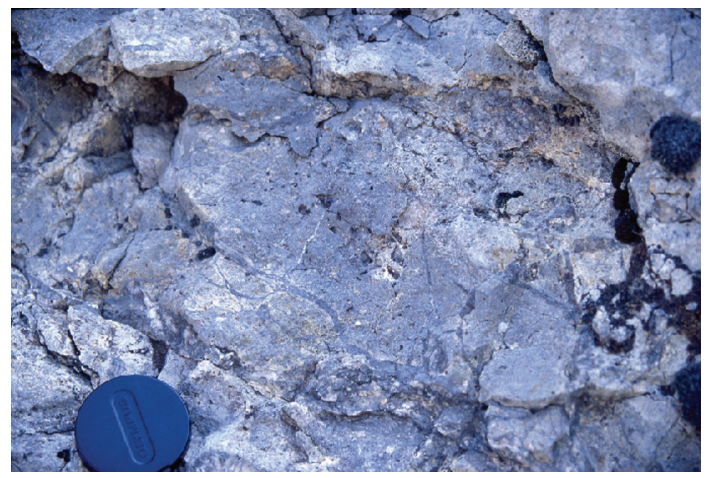

FIgURE 9: Vuggy structures associated with monogenic breccias and irregular network of carbonate-filled veins (diameter 3-4 mm), Castagno d'Andrea (number 25 of Figure 1).

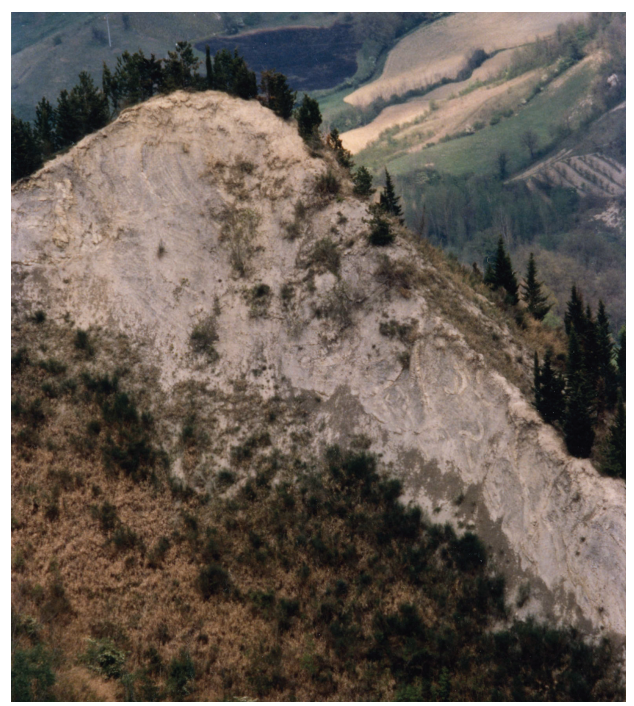

FIGURE 10: Intraformational slump in closure pelites of the foredeep, near Montepetra (number 47 of Figure 1).
Castagno d'Andrea; Figure 10), where carbonates are hosted in pelitic successions deposited in intrabasinal structural highs. The formation of structural highs is linked to synsedimentary thrust activity, related to blind thrusts. Intrabasinal highs are developed very close, some tens of kilometers, to the front of the paleo-Apennine wedge represented by the allochthonous Ligurian nappe. They formed during the closure stage of the foredeep, generally related to the synsedimentary growth of anticlines. Field analyses suggest that detachment folding was the leading mechanism of anticline growth and of synsedimentary instability along the anticline flanks. In this structural setting, the fold geometry can deflect and confine the mass transport deposits sourced from the Ligurian nappe (olistostromes). The occurrence of sediment sliding sourced both from intraformational and extraformational sediments, and the ascent of blocks of already compacted rocks and clasts from the underlying basin-plain turbidites of the Marnoso-arenacea Fm, in some cases seem to indicate a contribution from diapiric rising of fluids $[17,18]$. In the Epiligurian basins, seep carbonates are lateral to a huge sedimentary mélange (Montardone mélange; Figure 4) recently interpreted as a diapir on the basis of the distribution and geometry of the mélange, the vertical abrupt contact with the hosting Termina marls, the occurrence of huge seep carbonates associated with the mélange, and the presence of polygenic breccias at the base of carbonates.

The marginal portion of the diapir is characterized by diffuse slope instability with the emplacement of coalescent debris flows involving blocks of authigenic carbonates. Minor lens-like bodies of chaotic deposits are present in seep carbonates at different levels, resembling sill-like intrusions of diapiric material.

4.1.5. Isotopes. The $\partial^{13} \mathrm{C}$ and $\partial^{18} \mathrm{O}$ analyses indicate that examined seep carbonates are depleted in ${ }^{13} \mathrm{C}$ and slightly but significantly enriched in ${ }^{18} \mathrm{O}$ compared to carbonates of surrounding sediments. The ${ }^{13} \mathrm{C}$ depletion and ${ }^{18} \mathrm{O}$ enrichment reach the maximum values in the brecciated portions of the larger seep carbonates. In Sasso Streghe outcrops the carbon value has an average $=-37 \%$, and the $\partial^{18} \mathrm{O}$ value range from 0.1 to $5.4 \%$ relative to the PDB standard [19, and unpublished data]. In enclosing pelites values vary narrowly in most samples, showing a slight depletion in ${ }^{18} \mathrm{O}\left(\partial^{18} \mathrm{O}\right.$ from -3.11 to $-4.47 \%$ o $)$ that suggests derivation of oxygen from seawater. The Montepetra carbonates (MP5 and FC bodies, [17]) show negative carbon values (from -36.02 to $-52.68 \%$ ) associated with enriched values of ${ }^{18} \mathrm{O}$ ( $\partial^{18} \mathrm{O}$ from 2 to $5.97 \%$ ). The Castagno d'Andrea carbonates constituting the main massive micrite portion of the body show an average $\delta^{13} \mathrm{C}=-24 \%$ [16] and carbonates in the brecciated units have an average $=-36.0 \%$ PDB. The ${ }^{18} \mathrm{O}$ values $\left(\delta^{18} \mathrm{O}=+1.2 \%\right.$ PDB $)$ show a slight but significant enrichment in $\delta^{18} \mathrm{O}$ for chemoherms when compared to values of carbonate phases present in enclosing pelites. In samples from Poggio Campane the carbon values reach $-32.2 \%$ and $\partial^{18} \mathrm{O}+2.21 \%$. 


\section{Discussion}

In fossil Apenninic seep carbonates, we found structures that are very similar to "gas-hydrate related rock structures" reported by [1] in present-day carbonates of the Hydrate ridge in the Cascadia margin. In the Hydrate Ridge, the authors recognized a direct relationship between gas hydrates and sediment fracturing: carbonates show layered megapores and veins as relict of the original gas hydrate fabric, and different types of breccias formed by growing and decomposing gas hydrate near the sediment surface. In addition carbonates are involved in sedimentary instability processes. The heavy oxygen isotopic signatures are also a peculiar feature.

In the Miocene Apenninic seep carbonates, vacuolar and vuggy-like structures of irregular shape (Figures 7, 8, and 9) look similar to hydrate layers observed in modern sediments. Monogenic breccias (Figure 5) share many characters with mudclast breccias and intraformational breccias "chemoherm-typical," described in [1], and to "irregular edifices" reported in [39], due to ascending bubbles and growing gas hydrate that caused sediment brecciation. We do not esclude that part of these features are collapse breccia, related to the rapid destabilization of gas hydrates in the sediment pore spaces. Both recent and fossil breccias have very angular clasts, a similar irregular clast-supported fabric, and abundant pores. Polygenic breccias (Figure 6) in studied sediments are also similar to polymictic lithologies of [1]. The large dimensions of Miocene carbonate edifices (Figures 3 and 4) bearing brecciated structures, as well as the close association with sedimentary instabilities (Figures 4 and 10) are also reported in modern hydrate-associated settings. Geochemistry provides an additional evidence. Apenninic seep carbonates show negative carbon values $\left(\partial^{13} \mathrm{C}\right.$ up to $-52.68 \%$ o $)$ associated with enriched values of $18 \mathrm{O}\left(\partial^{18} \mathrm{O}\right.$ up to $5.97 \%$ ) that could be likely due to decomposition of gas hydrates.

All these elements seem to indicate that the decomposition of gas hydrates played a role in the precipitation of methane-derived carbonates in wedge-top and foredeep basins of the northern Apennines, during the Miocene. The gas hydrate destabilization was not substitutive but contributory to surface microbial methanogenesis and could permit a large amount of fluids to be released in a short time.

In the northern Apennines inferred paleobathymetric data are compatible with gas hydrate stability field [40], as estimated on the basis of benthic foraminiferal fauna characteristics, indicating intermediate water depth (upper slope) for the seep carbonates [17, 18].

We hypothesized different mechanisms in the foredeep and in wedge-top basins, resulting in geological responses largely dependent on rate and duration of fluid expulsion processes.

Carbonates in the foredeep (Castagno d'Andrea, Montepetra, Poggio delle Campane) are related to intrabasinal highs where methane accumulation in the hinge zone may form a hydrate seal, trapping methane in underlying strata. Tectonic movements could have disrupted the underlying gas hydrate stability zone, as a consequence of upward movement of the base of gas-hydrate stability field due to uplift of the structural highs (cf. [41]), and/or anomalous heating by waters moving up along faults [42, 43]. Seal rupture by tectonic activity allowed methane seepage that sustained chemosynthetic biota and consented carbonate precipitation. Gas hydrate dissociation produced large amount of gas and water released in a short time, thus favouring more intense fluid activity triggering mass wasting deposits, such as sliding and slumping, and sand/mud diapirism.

Decomposition of gas hydrates and weakening of the mechanical strength of sediments encouraged failure along low-angle slopes producing more slides and some slumps rather than debris flows, as indicated by [44] in modern geological settings. The lack of turbidity deposits at the foot of the slumps could be a further clue to their gas-hydrate dissociation-related origin. Fluid overpressures was probably facilitated by the tectonic loading of Apennine thrustsheets, related to underthrust foredeep deposits dewatering. The occurrence of extraformational deposits (olistostromes) within pelitic intervals testifies a close position of the deformational front. This intense activity could also explain the ascent of blocks of already compacted rocks and clasts from the underlying basin-plain turbidites.

In epiligurian wedge-top basins we hypothesize mud diapirism due to the tectonic loading by overthrusting, and the generation of a large amount of methane-rich fluid for gas-hydrate destabilization. The occurrence of methane-rich fluids, testified by authigenic carbonates, contributed to generate overpressured shales ascending along sin-sedimentary faults. The fine-grained nature of the matrix of buried debris flow deposits, common in epiligurian succession but absent in the foredeep, incorporated in the accreted terranes of the Apenninic thrusts, favoured the build-up of the excess pore pressure necessary for the evolution of mud diapirs. In our opinion, the polygenic extraformational breccias in epiligurian seep carbonates originated not only from hydrofracturing and erosion of the country rocks during gas hydrate destabilization and mud eruption, but also from the reworking of buried slides and debris flows, common in the epiligurian succession (sedimentary mélanges). The surface expression of the mud diapir is affected by diffuse slopeinstability with the emplacement of coalescent debris flows also involving blocks of authigenic carbonates.

\section{Conclusions}

Authigenic seep carbonates in the northern Apennines are concentrated in Middle-Late Miocene pelitic successions in two different geological settings: in the foredeep and in epiligurian wedge-top basins.

By comparison with present-day analogues, we infer a possible role of gas hydrates in the precipitation of fossil seep carbonates of the Apennines. The factors that have allowed us to hypothesize the paleo occurrence of gas hydrates are the heavy oxygen isotope signature, the presence of distinctive sedimentary features (breccias, soft sediment deformation) related to clathrites, the close association between seep carbonates and sedimentary instabilities, and 
the large dimensions of seep carbonate deposition bearing brecciated structures.

Carbonates in the foredeep are related to intrabasinal highs where methane accumulation in the hinge zone formed a hydrate seal, trapping methane in underlying strata. Seal rupture by tectonic activity induced gas hydrate dissociation, resulting in carbonate precipitation and triggering mass wasting deposits. Decomposition of gas hydrates and weakening of the mechanical strength of sediments encouraged failure along low-angle slopes producing more slides and some slumps rather than debris flows.

In epiligurian wedge-top basins, carbonates are associated with a diapiric mélange, generated by overpressured shales ascending along sin-sedimentary faults, related to gas hydrate dissociation. We assumed that the fine-grained nature of the matrix of buried debris flow deposits, common in epiligurian succession but absent in the foredeep, favoured the build-up of the excess pore pressure necessary for the evolution of mud diapir. The polygenic extraformational breccias in epiligurian seep carbonates originated not only from hydrofracturing and erosion of the country rocks during gas hydrate destabilization and mud eruption, but also from the reworking of buried slides and debris flows.

\section{Acknowledgments}

The authors are grateful for all the suggestions of the editor, and the careful revisions of the anonymous reviewers who greatly improved the original paper.

\section{References}

[1] J. Greinert, G. Bohrmann, and E. Suess, "Gas hydrateassociated carbonates and methane-venting at Hydrate Ridge: classification, distribution, and origin of authigenic lithologies," in Natural Gas Hydrates: Occurrence, Distribution and Detection, C. K Paull and W. P. Dillon, Eds., Geophysical Monograph 124, pp. 99-113, 2001.

[2] L. L. Mazurenko and V. A. Soloviev, "Worldwide distribution of deep-water fluid venting and potential occurences of gas hydrate accumulations," Geo-Marine Letters, vol. 23, no. 3-4, pp. 162-176, 2003.

[3] A. Mazzini, H. Svensen, M. Hovland, and S. Planke, "Comparison and implications from strikingly different authigenic carbonates in a Nyegga complex pockmark, G11, Norwegian Sea," Marine Geology, vol. 231, no. 1-4, pp. 89-102, 2006.

[4] J. P. Kennett and B. N. Fackler-Adams, "Relationship of clathrate instability to sediment deformation in the upper Neogene of California," Geology, vol. 28, no. 3, pp. 215-218, 2000.

[5] G. Bohrmann, K. Heeschen, C. Jung et al., "Widespread fluid expulsion along the seafloor of the Costa Rica convergent margin," Terra Nova, vol. 14, no. 2, pp. 69-79, 2002.

[6] H. H. Roberts, "Fluid and gas expulsion on the Northern Gulf of Mexico continental slope: mud-prone to mineral-prone responses," in Natural Gas Hydrates: Occurrence, Distribution and Detection, C. K. Paull and W. P. Dillon, Eds., Geophysical Monograph 124, pp. 145-161, 2001.

[7] X. Han, E. Suess, Y. Huang et al., "Jiulong methane reef: microbial mediation of seep carbonates in the South China Sea," Marine Geology, vol. 249, no. 3-4, pp. 243-256, 2008.
[8] G. Bohrmann and M. E. Torres, "Gas hydrates in marine sediments," in Marine Geochemistry, H. D. Schulz and M. Zabel, Eds., pp. 481-512, Springer, Berlin, Germany, 2006.

[9] B. M. A. Teichert, N. Gussone, A. Eisenhauer, and G. Bohrmann, "Clathrites: archives of near-seafloor pore-fluid evolution $\left(\delta^{44 / 40} \mathrm{Ca}, \delta^{13} \mathrm{C}, \delta^{18} \mathrm{O}\right)$ in gas hydrate environments," Geology, vol. 33, no. 3, pp. 213-216, 2005.

[10] F. F. Krause, "Genesis and geometry of the Meiklejohn Peak lime mud-mound, bare mountain quadrangle, Nevada, USA: ordovician limestone with submarine frost heave structuresA possible response to gas clathrate hydrate evolution," Sedimentary Geology, vol. 145, no. 3-4, pp. 189-213, 2001.

[11] C. Pierre and J. M. Rouchy, "Isotopic compositions of diagenetic dolomites in the Tortonian marls of the western Mediterranean margins: evidence of past gas hydrate formation and dissociation," Chemical Geology, vol. 205, no. 3-4, pp. 469-484, 2004.

[12] M. J. Bojanowski, "Oligocene cold-seep carbonates from the Carpathians and their inferred relation to gas hydrates," Facies, vol. 53, no. 3, pp. 347-360, 2007.

[13] F. D. Pierre, L. Martire, M. Natalicchio, P. Clari, and C. Petrea, "Authigenic carbonates in upper miocene sediments of the tertiary piedmont basin (NW Italy): vestiges of an ancient gas hydrate stability zone?" Bulletin of the Geological Society of America, vol. 122, no. 7-8, pp. 994-1010, 2010.

[14] L. Martire, M. Natalicchio, C. C. Petrea, S. Cavagna, P. Clari, and F. D. Pierre, "Petrographic evidence of the past occurrence of gas hydrates in the Tertiary Piedmont Basin (NW Italy)," Geo-Marine Letters, vol. 30, no. 3-4, pp. 461-476, 2010.

[15] S. Conti and D. Fontana, "Miocene chemoherms of the northern Apennines, Italy," Geology, vol. 27, no. 10, pp. 927930, 1999.

[16] S. Conti, D. Fontana, A. Gubertini et al., "A multidisciplinary study of middle Miocene seep-carbonates from the northern Apennine foredeep (Italy)," Sedimentary Geology, vol. 169, no. 1-2, pp. 1-19, 2004.

[17] S. Conti, D. Fontana, S. Mecozzi, G. Panieri, and G. A. Pini, "Late Miocene seep-carbonates and fluid migration on top of the Montepetra intrabasinal high (Northern Apennines, Italy): relations with synsedimentary folding," Sedimentary Geology, vol. 231, no. 1-2, pp. 41-54, 2010.

[18] G. Panieri, A. Camerlenghi, S. Conti, G. A. Pini, and I. Cacho, "Methane seepages recorded in benthic foraminifera from Miocene seep carbonates, Northern Apennines (Italy)," Palaeogeography, Palaeoclimatology, Palaeoecology, vol. 284, no. 3-4, pp. 271-282, 2009.

[19] S. Conti and D. Fontana, "Anatomy of seep-carbonates: ancient examples from the Miocene of the northern Apennines (Italy)," Palaeogeography, Palaeoclimatology, Palaeoecology, vol. 227, no. 1-3, pp. 156-175, 2005.

[20] W. Cavazza, F. M. Roure, W. Spackman, G. M. Stampali, and P. A. Ziegler, The TRANSMED Atlas. The Mediterranean Region from Crust to Mantle, Springer, Berlin, Germany, 2004.

[21] C. Doglioni, F. Monelli, and G. Pialli, "Boudinage of the Alpine belt in the Apenninic back-arc," Memorie Della Societa' Geologica Italiana, vol. 52, pp. 457-468, 1998.

[22] E. Gueguen, C. Doglioni, and M. Fernandez, "On the post25 Ma geodynamic evolution of the western Mediterranean," Tectonophysics, vol. 298, no. 1-3, pp. 259-269, 1998.

[23] A. Argnani and F. Ricci Lucchi, "Tertiary silicoclastic turbidite systems of the Northern Apennines," in Anatomy of an Orogen: The Apennines and Adjacent Mediterranean Basins, I. P. Martini and G. B. Vai, Eds., pp. 327-350, Kluwer Academic, London, UK, 2001. 
[24] G. Muttoni, L. Lanci, A. Argnani et al., "Paleomagnetic evidence for a neogene two-phase counterclock wise tectonic rotation in the Northern Apennines (Italy)," Tectonophysics, vol. 326, no. 3-4, pp. 241-253, 2000.

[25] J. Ferrandini, J. Gattacceca, M. Ferrandini, A. Deino, and M. C. Janin, "Chronostratigraphy and paleomagnetism of OligoMiocene deposits of Corsica (France): geodynamic implications for the liguro-provençal basin spreading," Bulletin de la Societe Geologique de France, vol. 174, no. 4, pp. 357-371, 2003.

[26] M. Marroni, G. Molli, A. Montanini, G. Ottria, L. Pandolfi, and R. Tribuzio, "The external Ligurian units (Northern Apennine, Italy): from rifting to convergence of a fossil oceancontinent transition zone," Ofioliti, vol. 27, pp. 119-131, 2002.

[27] A. Amorosi, M. L. Colalongo, and S. C. Vaiani, "Le unità epiliguri mioceniche nel settore emiliano dell'Appennino settentrionale. Biostratigrafia, stratigrafia sequenziale e implicazioni litostratigrafiche," Palaeopelagos, vol. 3, pp. 209-240, 1993.

[28] E. Mutti, L. Papani, D. Di Biase et al., "Il bacino terziario epimesoalpino e le sue implicazioni sui rapporti tra Alpi ed Apennino," Memorie di Scienze Geologiche, Università di Padova, vol. 47, pp. 217-244, 1995.

[29] G. Ottria, R. Catanzariti, and A. C. Feroni, “The Ranzano unit boundaries in the type area: lower Oligocene events in the epi-Ligurian Succession (northern Apennines, Italy)," Eclogae Geologicae Helvetiae, vol. 94, no. 2, pp. 185-196, 2001.

[30] U. Cibin, E. Spadafora, G. G. Zuffa, and A. Castellarin, "Continental collision history from arenites of episutural basins in the Northern Apennines, Italy," Bulletin of the Geological Society of America, vol. 113, no. 1, pp. 4-19, 2001.

[31] S. Conti and R. Gelmini, "Miocene-Pliocene tectonic phases and migration of foredeep-thrust belt system in Northern Apennines," Memorie Della Societa' Geologica Italiana, vol. 48, pp. 261-274, 1994.

[32] G. A Pini, "Tectosomes and olistostromes in the argille scagliose of Northern Apennines ," Geological Society of America, pp. 1-70, 1999, Special Paper 335.

[33] G. Papani, C. Tellini, L. Torelli, L. Vernia, and S. Iaccarino, "Nuovi dati stratigrafici e strutturali sulla Formazione di Bismantova nella "sinclinale" Vetto-Carpineti (Appennino reggiano-parmense)," Memorie Della Societa' Geologica Italiana, vol. 39, pp. 245-275, 1987.

[34] A. Artoni, G. Papani, F. Rizzini et al., "The salsomaggiore structure (Northwestern Apennine foothills, Italy): a Messinian mountain front shaped by mass-wasting products," GeoActa, vol. 3, pp. 107-127, 2004.

[35] C. C. Lucente and G. A. Pini, "Anatomy and emplacement mechanism of a large submarine slide within a miocene foredeep in the Northern Apennines, Italy: a field perspective," American Journal of Science, vol. 303, no. 7, pp. 565-602, 2003.

[36] C. C. Lucente and M. Taviani, "Chemosynthetic communities as fingerprints of submarine sliding-linked hydrocarbon seepage, Miocene deep-sea strata of the Tuscan-Romagna Apennines, Italy," Palaeogeography, Palaeoclimatology, Palaeoecology, vol. 227, no. 1-3, pp. 176-190, 2005.

[37] F. Ricci Lucchi and G. B. Vai, "A stratigraphic and tectonofacies framework of the "calcari a Lucina" in the Apennine Chain, Italy," Geo-Marine Letters, vol. 14, no. 2-3, pp. 210-218, 1994.

[38] S. Conti and D. Fontana, "Sediment instability related to fluid venting in Miocene authigenic carbonate deposits of the northern Apennines (Italy)," International Journal of Earth Sciences, vol. 91, no. 6, pp. 1030-1040, 2002.
[39] L. D. Kulm and E. Suess, "Relationship between carbonate deposits and fluid venting: oregon accretionary prism," Journal of Geophysical Research, vol. 95, no. 6, pp. 8899-8915, 1990.

[40] G. R. Dickens and M. S. Quinby-Hunt, "Methane hydrate stability in seawater," Geophysical Research Letters, vol. 21, no. 19, pp. 2115-2118, 1994.

[41] K. Sain, T. A. Minshull, S. C. Singh, and R. W. Hobbs, "Evidence for a thick free gas layer beneath the bottom simulating reflector in the Makran accretionary prism," Marine Geology, vol. 164, no. 1-2, pp. 3-12, 2000.

[42] A. Y. Golmshtok, A. D. Duchkov, D. R. Hutchinson, and S. B. Khanukaev, "Heat flow and gas hydrates of the Baikal rift zone," International Journal of Earth Sciences, vol. 89, no. 2, pp. 193-211, 2000.

[43] M. D. Tryon, K. M. Brown, M. E. Torres, A. M. Tréhu, J. McManus, and R. W. Collier, "Measurements of transience and downward fluid flow near episodic methane gas vents, Hydrate Ridge, Cascadia," Geology, vol. 27, no. 12, pp. 10751078, 1999.

[44] B.U. Haq, "Natural gas hydrates: searching for the longterm climatic and slope-stability records," in Gas Hydrates: Relevance To World Marginn Stability And Climate Change, J. P. Henriet and J. Mienert, Eds., Special Publication No.137, pp. 303-318, Geological Society, London, UK, 1998. 

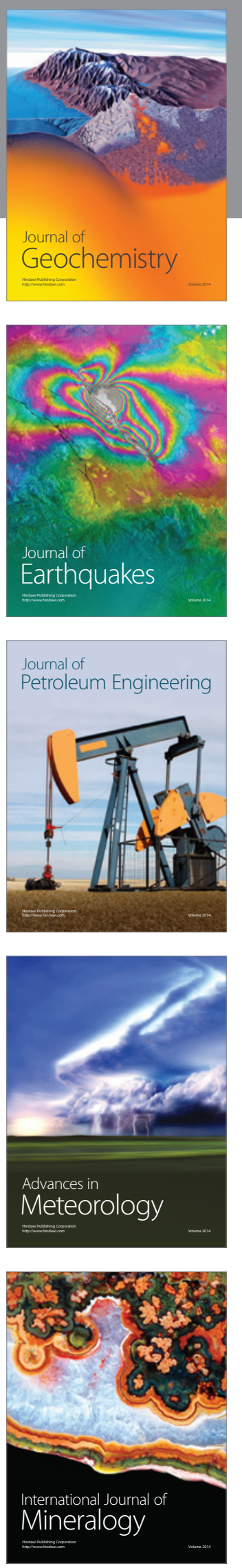
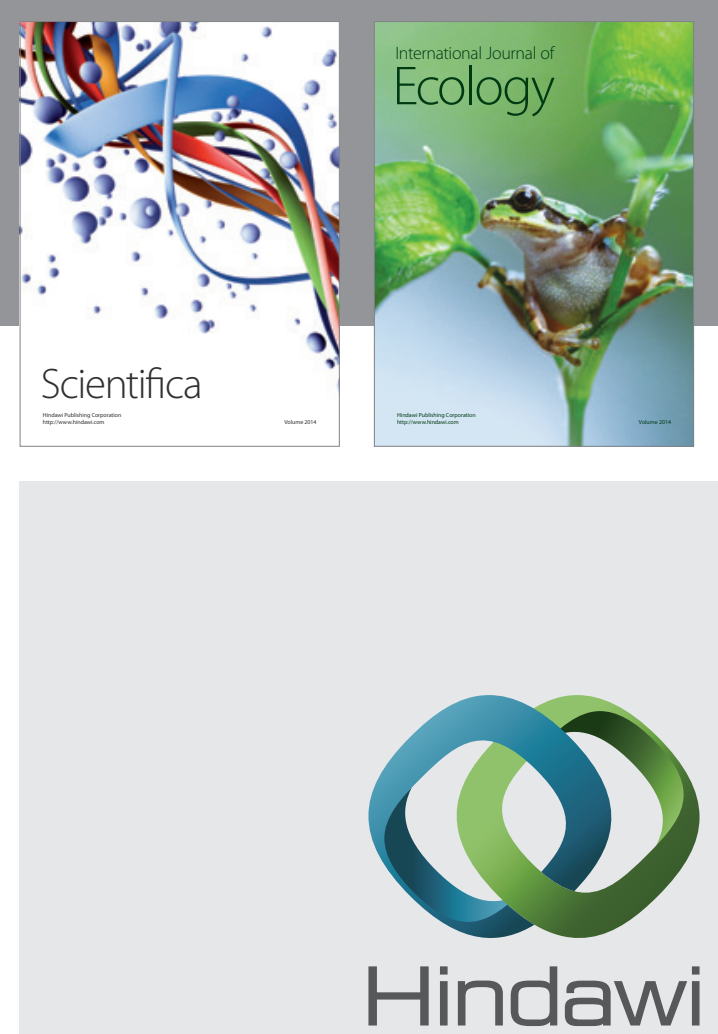

Submit your manuscripts at http://www.hindawi.com
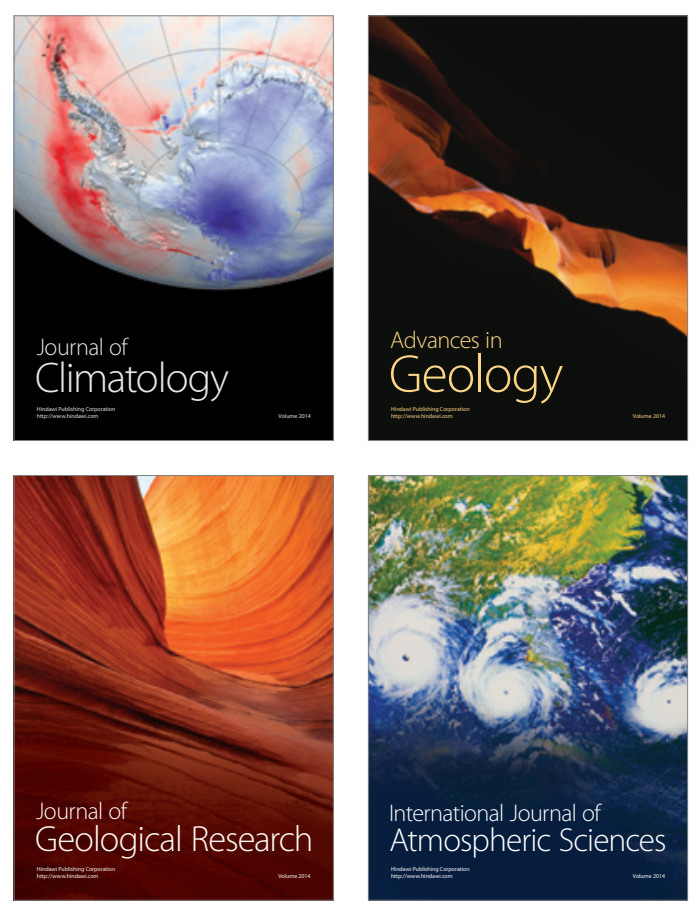
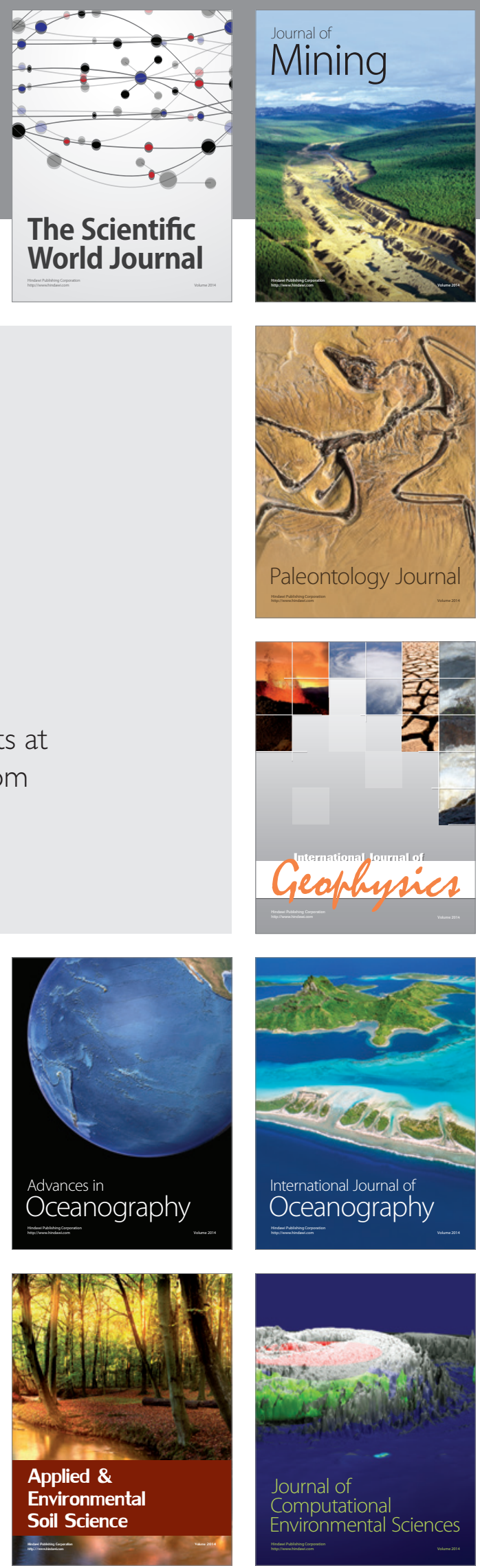